\title{
Colombia in 2019: The Paradox of Plenty*
}

\author{
Colombia en 2019: la paradoja de la abundancia
}

\author{
ANGELIKA RETTBERG \\ Universidad de los Andes, Colombia
}

\begin{abstract}
2019 was a significant year for Colombian politics and the country's political debate was dominated by four intertwined issues: (a) the implementation of the historic peace agreement between the Colombian government and the Fuerzas Armadas Revolucionarias de Colombia (FARC) and all its economic, judicial, and political ramifications, (b) the ongoing presence of illicit crops and the impact of the drug trade on domestic and international security, (c) the tense bilateral relation between Colombia and Venezuela, and, similar to other Latin American countries, (d) social unrest caused by multiple and widespread frustration about public education, health, corruption, governance, and the environment. At the same time, the country was marked by steady economic growth, above the Latin American average. In addition, much of the political debate took place within and among the institutions of Colombian state and society, illustrating growing state capacity and a mature civil society. In this article, I describe the different aspects of this Colombian paradoxhigh levels of domestic unrest and political polarization surrounding unsolved structural issues and pending expectations about peace combined with superior economic performance and growing institutional strength-in an effort to provide an overview of the challenges overcome as well as those lying ahead.
\end{abstract}

Keywords: Peace agreement, transitional justice, illicit crops, migration, protest, Colombia.

\begin{abstract}
RESUMEN
2019 fue un año significativo para la política colombiana. El debate político estuvo dominado por cuatro temas relacionados: (a) la implementación de un acuerdo de paz de envergadura histórica entre el Gobierno nacional y las Fuerzas Armadas Revolucionarias de Colombia (FARC) y todas sus ramificaciones económicas, judiciales y políticas, (b) la continua presencia de cultivos ilícitos y el impacto del narcotráfico en la seguridad doméstica y exterior, (c) la tensa relación bilateral entre Colombia y Venezuela y, parecido a otros países latinoamericanos, (d) la agitación social causada por la frustración generalizada con la educación pública, la salud, la corrupción, la gobernanza y el medio ambiente. Al mismo tiempo, el país estuvo marcado por un crecimiento económico constante, por encima del promedio latinoamericano. Además, una buena parte del debate político tuvo lugar en el marco y en torno a las instituciones del Estado y la sociedad colombianas, ilustrando una creciente capacidad institucional y una sociedad civil madura. En este artículo, describo los diferentes aspectos de la paradoja de la abundancia colombiana —altos niveles de agitación social y polarización política en torno a asunto estructurales no resueltos y expectativas pendientes sobre la paz, en combinación con desempeño económico superior y creciente capacidad institucional —en un esfuerzo por brindar una visión panorámica de los desafíos superados y los que están por venir.
\end{abstract}

Palabras clave: acuerdo de paz, justicia transicional, cultivos ilícitos, migración, protesta, Colombia. 


\section{INTRODUCTION}

2019 was a significant year for Colombia. The country's political debate was dominated by four intertwined issues: the implementation of the historic peace agreement between the Colombian government and the Fuerzas Armadas Revolucionarias de Colombia (FARC) and all its economic, judicial, and political ramifications, the ongoing presence of illicit crops and the impact of the drug trade on domestic and international security, the tense bilateral relation between Colombia and Venezuela, and, similar to other Latin American countries, social unrest caused by multiple and widespread frustration about public education, health, corruption, governance, and the environment.

At the same time, the country was marked by steady economic growth (above the Latin American average, see figure 1) and achieved important milestones, such as admission to the Organization for Economic Co-operation and Development (OECD) in 2018. In addition, much of the public debate took place within and among the institutions of Colombian state and society, a fact that often remains unnoticed among observers. In fact, to the eyes of many countries and international organizations, in contrast both with the region and with its own past, Colombia has progressed from problem child to regional darling in terms of democratic consolidation, institutional capacity, and economic development. In this article, I describe the different aspects of this Colombian paradox-high levels of domestic unrest and political polarization surrounding unsolved structural issues and pending expectations about peace combined with superior economic performance and growing institutional strength - in an effort to provide an overview of the challenges overcome as well as those lying ahead.

Figure 1. GDP growth (annual \%), Colombia and Latin America and the Caribbean (1990 - 2018)

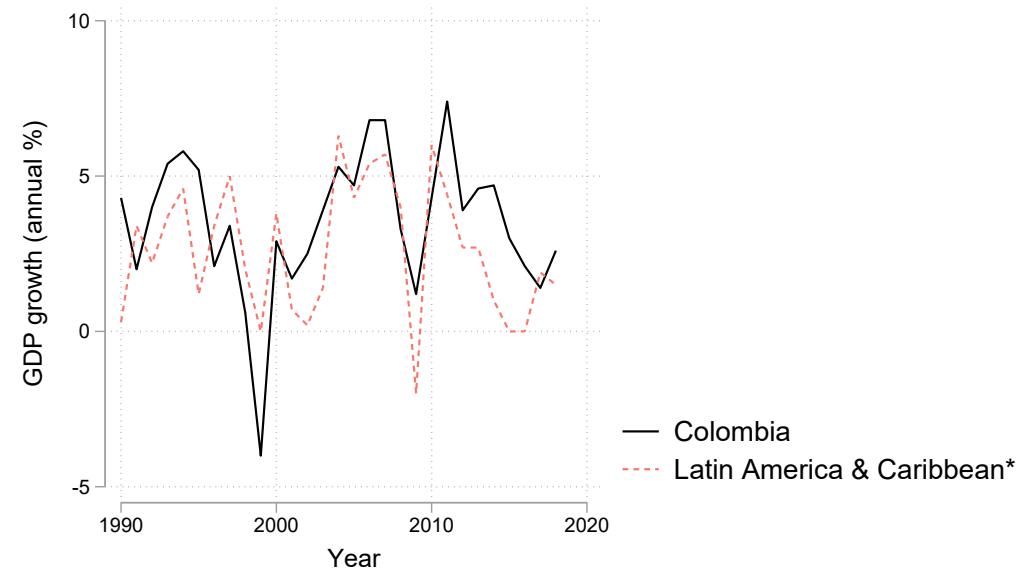


The document will first present progress and challenges related to the peace agreement with FARC and discuss the situation of the remaining groups as well as ongoing crime. Then, it will present the situation of illicit crops and the drug trade, which have a direct impact on Colombia's security and political stability. Third, the document will lay out the relationship with Venezuela, with a special focus on shifting attitudes towards Venezuelans and growing xenophobia. Finally, the document will analyze how many of the frustrations vented in the end-of-the-year stoppages and manifestations illustrate-as in other Latin American countries - the limitations of a policy model in which many feel their needs and expectations are not sufficiently addressed.

\section{ARMED CONFLICT, PEACE AGREEMENT, GUERRILLA REMNANTS, AND NEW FORMS OF CRIME}

In 2016 a peace agreement put an end to a decade-long conflict with one of the largest and oldest Latin American guerrillas, the FARC. The agreement set out to address rural reform, illicit crops, political participation of minority groups, and transitional justice. In addition to producing the demobilization of fighters, the agreement was guided by an interest in strengthening inclusion-promoting institutions and social relations as well as the development of heretofore underprivileged regions of the country (IFIT 2018). Reflecting international support for this purpose, then UN Secretary General Ban Ki Moon referred to Colombia's peace agreement as "a bright flare of hope" (UN News Centre Press 2016) at the global level.

Colombia is still the one of the most violent countries in Latin America-which is the most violent region in the world (Rettberg 2020), but homicides have decreased substantially, especially those related to the armed conflict (figure 2).

Figure 2. Homicides (rate and absolute numbers), Colombia, 2009 - 2019

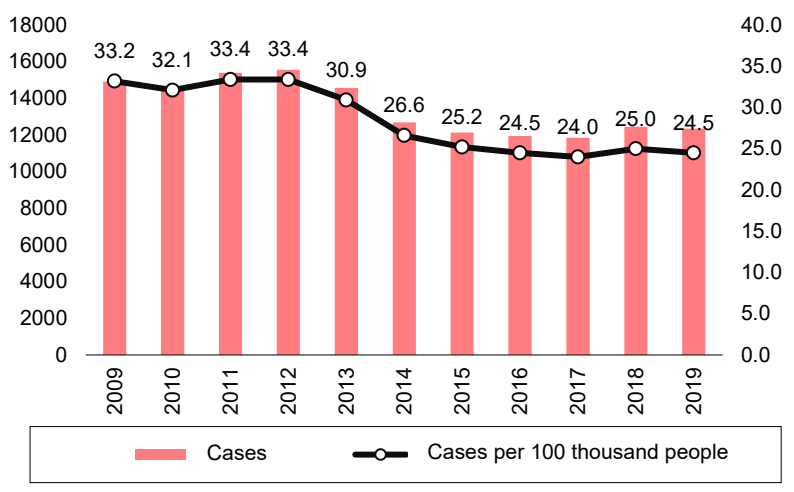


Similarly, kidnappings have declined, as has forced displacement, the dominant form of victimization among the more than eight million Colombians who have registered as victims of armed conflict with the Colombian state (figure 3) (Victims' Unit 2020). Subversive action, too, has decreased substantially (figure 4).

Figure 3. Forced displacements, Colombia, 1985 - 2018, in thousands.

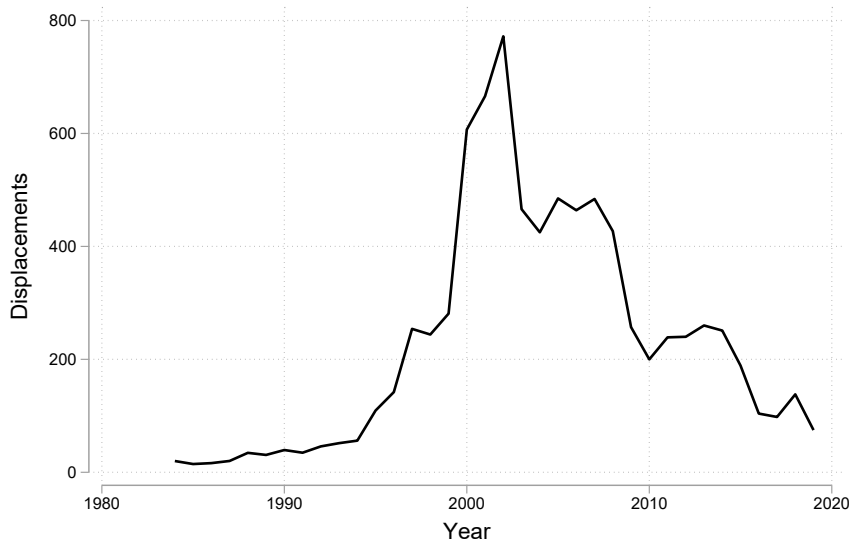

Source: UNOCHA (2019).

Figure 4. Subversive actions, Colombia, 2010 - 2019

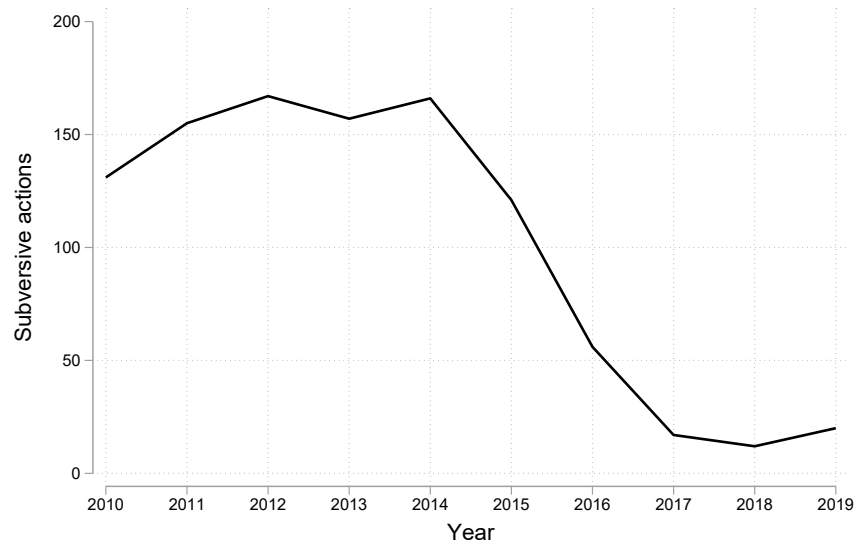

Source: Ministry of Defense (2020).

In 2019, most of the more than twenty agencies and offices that rolled out the Colombian peacebuilding infrastructure-before, during, and after the peace process-were operating in areas such as rural transformation, attention to demobilized fighters and victims, finding the disappeared, providing truth 
and memory, and promoting transitional justice. In doing so, they benefited from decades of expertise and legal development in all of these areas (Rettberg 2019a).

FARC, the party (formerly guerrilla) has developed a legislative agenda making use of the ten congressional seats for two consecutive terms that were granted by the peace agreement. It follows small-party strategies such as seeking alliances, building coalitions, and avoiding conflict and confrontation (Rettberg 2019b). However, its participation in elections was frustrating, earning them less than 1 percent of the national vote in the legislative elections of $2018 .{ }^{1}$ In the 2019 local elections for mayors and local councils one former FARC member was elected major in the 70,000 population Northern municipality of Turbaco (another former FARC member was elected mayor of Puerto Caicedo (Putumayo), a 14,000 population town in the South of Colombia, supported by a coalition of small parties). However, the party was not able to earn the necessary votes for any of the other 308 positions it competed for (El Tiempo 2019). FARC's electoral performance flew in the face of many predictions and electoral rants that predicted FARC were going to "take over" the country after the peace accords. ${ }^{2}$

While not as frustrating as FARC's results, elections were also marked by the decreasing performance of their main political opponents, the Centro Democrático Party. Its name notwithstanding, the party has been associated with the political Right and a rallying ground for supporters of former president Álvaro Uribe, who has led the strongest opposition to the peace accord. In the 2019 local elections it saw a reduction of approximately $20 \%$ in its vote count, in contrast with previous elections (Semana 2019a). The fact was recognized by this historical tweet by Álvaro Uribe (see illustration 1). For many observers the results of the 2019 elections signaled generalized fatigue with political polarization and broadening political space for the center of the ideological spectrum, as exemplified by the election of a gay woman with a progressive environmental agenda for the capital's mayor's office. The results also speak to the argument that, despite fierce discussions over the need, the merits, and the contents of Colombia's peace agreement, even harshest opponents appear to value democratic means, a fact that is worth underscoring in the Latin American context.

For proper context, the electoral threshold in the 2019 elections was 3\%. Were it not for the seats granted by the peace agreement, FARC would not have earned any congressional representation (Congreso Visible 2020; Misión de Observación Electoral 2018).

I thank an anonymous reviewer for pointing out the need to underscore this. 
Illustration 1 . Tweet by Álvaro Uribe, after his party's poor showing in the October 2019 local elections: "We lost, I recognize our defeat with humility. The fight for democracy never ends." (translation by author).

\author{
A. Álvaro Uribe Vélez \\ @AlvaroUribeVel \\ Perdimos, reconozco la derrota con humildad. La lucha \\ por la democracia no tiene fin. \\ 8:32 p. m. $\cdot 27$ oct. $2019 \cdot$ Twitter for iPhone
}

12,1 mil Retweets y comentarios $\quad 30,7$ mil Me gusta

In part due to its poor electoral showing, FARC has been ineffective in keeping the organization together. This illustrates the challenges of turning a militaristic guerrilla into a political party playing the formal rules of internal and systemic democracy. It also raises concerns about the risk of fragmentation. Most notably, FARC's chief negotiator-aka Iván Márquez-, who signed the peace agreement in 2016, reneged on his commitment in August 2019 and declared a return to armed struggle. The move was preceded and spurred by an indictment by the US Drug Enforcement Agency's (DEA) and the Colombian Prosecutor's Office of aka Jesús Santrich, Iván Márquez' close ally, accused of ongoing participation in the drug trade. In addition to this high-profile breakup, other former FARC leaders have publicly stated their disagreement with the course of action the party is taking and have splintered away (although they have stopped short from re-joining the armed struggle).

Groups led by FARC dissidents-some of which had announced their disapproval of negotiations since the peace process, while others joined later-are active in over 100 of the over 1,103 Colombian municipalities, especially in areas marked by illicit crops (El Tiempo 2020). Human Rights defenders and social leaders are getting killed in rural areas, especially in four departments (Antioquia, Arauca, Cauca, and Caquetá). 77 FARC members were killed, "making 2019 the most violent year for former combatants", "compared to 65 in 2018 and 31 in 2017" (UN Verification Mission 2019). All the regions in which these killings take place are marked by endemic violence, illicit economies and the presence of criminal organizations (some linked to Mexican cartels) and the ELN, the one remaining Colombian guerrilla concentrated (UNHCHR 2020).

24 Espacios territoriales de capacitación y reincorporación (Territorial capacity-formation and reincorporation spaces - ETCR for their Spanish acronym), or camps hosting former FARC fighters and their families, are still active (Agencia de Reincorporación Nacional - ARN - 2020a). Following demobilization, former combatants were formerly registered in the public health, pension, and financial system (Agencia de Reincorporación Nacional - ARN - 2020b). Territo- 
rial peace programs, which were part of the agreement with FARC and are aimed at addressing historical institutional and developmental shortages in the most conflict-affected regions, are being developed by the Officer of the High Commissioner for Stabilization and Consolidation (the euphemism with which the government of president Iván Duque has managed to downplay the word "peace", associated with his predecessor and political opponent, president Juan Manuel Santos) in 170 municipalities. However, rural reform, a central component of the peace agreement, is the least developed of the agreement's commitments (UNHCHR 2020).

Central to the peace agreement were transitional justice mechanisms, which have been under continuous yet overall unsuccessful attack (Nasi and Rettberg 2019). The Comprehensive System of Truth, Justice, Reparation, and Non-Repetition, which builds on transitional justice mechanisms developed since 2005, is made up of the Special Peace Jurisdiction, designed to learn about crimes committed in the course of the conflict by FARC, members of the Armed Forces, other state agents and civilian third parties, the Truth, Coexistence and Non-Repetition Commission, the Special Jurisdiction for Peace (JEP), and the Unit for the Search for Persons Presumed Disappeared in the context and by reason of the armed conflict (UBPD); as well as of comprehensive reparation measures for peacebuilding and guarantees of non-repetition (JEP 2020a).

Hard-liners within the government coalition pushed the Duque government to raise objections to the JEP, deemed to be too lenient on FARC crimes. However, these were declared unconstitutional by the Constitutional Court in May 2019. During 2019, the JEP made important progress on the so-called "macro-cases", or representations of the main crimes committed in the course of the conflict (such as thousands of kidnappings, the recruitment of minors, and the so-called "false positives" or deaths of innocent civilians in response to the Armed Forces' body count policy) (International Commission of Jurists 2019). Close to 13,000 persons have requested to be heard by the JEP, most of them former members of FARC, but also members of the Armed Forces (20 percent) and third-party civilians (JEP 2020b). In the context of these macro-cases, JEP was able to collect versions on their responsibility in over 9,000 cases of kidnappings from the more than twenty members of FARC's former top Secretariat, including its highest commander, aka Timochenko. The year ended with the exhumation of over 50 bodies from the Dabeiba (Antioquia) cemetery, who died in the context of the Armed Forces' body count policy, which is estimated to be responsible for over 4,000 deaths (Acemoglu et al 2018; JEP 2019; Semana 2020b). In December 2019 Guillermo Botero offered his resignation to the Ministry of Defense, as a result of the process of political control against him in Congress, following the death of several minors in an Armed Forces bombing against FARC dissidents.

Parallel to these events, the president and the Constitutional Court prolonged the validity of the Victims' Law for ten more years, extending its duration un- 
til 2031. In 2011, the "Victims and Land Restitution Law" (Law 1448) built on achievements first introduced by the 2005 "Justice and Peace Law" (Law 975) which centered state attention on victims of the armed conflict, promising truth, reparations, and participation in victim-related policymaking (Rettberg 2015). The law and its achievements have been celebrated worldwide, as around eight million Colombians were formerly included in the National Victims' Registry, a bold move for any transitional country. The decision has also been questioned for being overly ambitious and lofty (Sikkink et al. 2015), as the likelihood for the state's fiscal and political capacity to deliver on reparation promises has proven to be low. Extending the deadline has thus bought critical time for state authorities in light of the low rate of reparations that have been awarded so far. In February 2019 a change in leadership of the Centro de Memoria Histórica, appointing a historian ideologically close to the president's coalition, illustrated the desire to re-shape the narratives about the Colombian conflict. Several organizations objected to the turn in historical memory policy, retrieved their records from the center, and questioned the government's willingness to keep its commitment to their efforts. In the meantime, the Truth Commission is moving forward, collecting versions of what happened during the conflict-including an account by the Colombian Air Force (Cifuentes and Mezú 2020) - and is due to publish its report in 2021.

Many of these disputes and decisions over the shape, duration, and content of agreement implementation, in general, and transitional justice, in particular reflect intense competition among political leaders and institutions over resources, domestic and international attention, overlapping functions, and mandates, reminding us that peacebuilding is an eminently political process (Rettberg 2019a). Saffon and Güiza (2019), for example, identify the debate over the peace agreement as a reflection of programmatic discussions among the Left and the Right.

The deeply contentious debate is also a reminder that the majority of the resources for the Colombian peace will come from Colombian pockets, including taxpayers' contributions and government credits (Consejería Presidencial para la Estabilización y la Consolidación 2020). ${ }^{3}$ Although the international community has pledged significant amounts of resources, the discussion over what peace-related policy should be implemented and how is also a discussion about national priorities and intense competition over scarce resources. In contrast with other transitional societies, in which foreign countries shouldered the brunt of peace-related costs (such as Guatemala), the Colombian peace will be as good (or as bad) as Colombian authorities and political leaders are willing to go. This improves the sense of local ownership, but also exposes the peace

The Colombian Peace Fund (Fondo "Colombia en Paz") draws its resources from the General National Budget, the System of Royalties, private donors, and international cooperation (Consejería Presidencial para la Estabilización y la Consolidación 2020). 
agreement the vagaries of post-negotiation competition with other policy areas needing attention.

However, these issues do not seem to resonate with the average Colombian, who understands and cares very little about many of the aspects of the intricate peace and transitional justice infrastructure (see figure 5 for information on knowledge of the JEP's sentencing scheme as a proxy for overall knowledge of the peace agreement) and is more concerned with other issues such as corruption and unemployment (Centro de Memoria Histórica 2012; Observatorio de la Democracia 2019).

Figure 5. Knowledge of the JEP's sentencing scheme

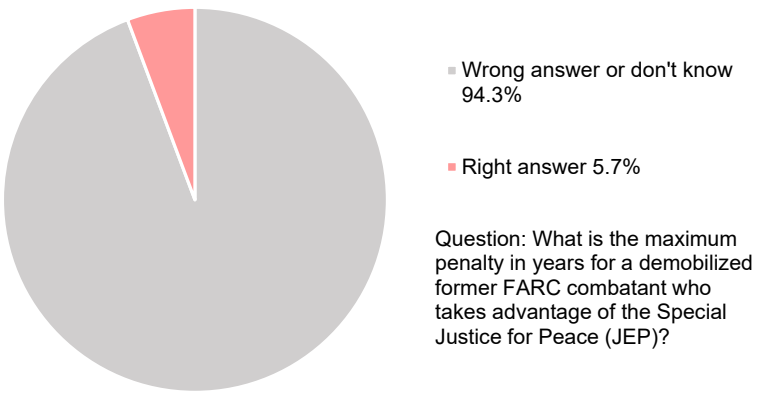

Source: LAPOP (2018)

As if the vagaries of implementing the FARC agreement weren't enough, Colombia's other guerrilla, the Ejército de Liberación Nacional (ELN), has stepped up its activity. Most notably, a bomb planted in a Police Academy in Bogotá in January cost the lives of around 20 cadets, motivating the Duque government to officially end an already languishing negotiation process. In addition, ELN has increased its military presence and recruitment along the Pacific coast and the Eastern border with Venezuela (especially along the so-called mining arc) (Fundación Ideas para la Paz 2019; Idler 2019). It is responsible for many of the killings of social leaders in their areas of influence. Illustrating the links between Colombia's domestic security policy and its foreign commitments, the ELN issue has caused repeated friction with Cuba, Venezuela, and the countries serving as international guarantors for that peace process, such as Norway. For example, following the decision to suspend negotiations after ELN's attack on the Police in January 2019, the Colombian government declared it would not comply with the return protocols that the international guarantors had agreed on for an exit scenario (which provided security guarantees for guerrilla commanders to return to Colombia or Venezuela), and demanded the Cuban government to extradite ELN negotiators. This jeopardized future negotiation efforts as it questioned the credibility of these protocols, put Cuba in 
an unsustainable position and actually exposed it to the risk of returning to the US list of states collaborating with terrorism.

In sum, on the one hand, there has been dissatisfaction with the slow speed of the implementation process, as well as the ongoing lure of the drug trade, which seem to explain both the return to illegality of former FARC members as well as the continuation of criminal activity by long-standing organizations such as the ELN, challenging security and stability. On the other hand, FARC's conversion into political party, a significant peace and transitional justice infrastructure, and extant efforts to promote sustainable demobilization and territorial peace is yielding important results in the purpose of finding truth and promoting the reduction of political violence in the country.

\section{ILLICIT CROPS AND THE DRUG TRADE}

War economies shape the forms and intensity of postwar crime (Kurtenbach and Rettberg 2020). In Colombia, illicit crops have been responsible for the escalation of violence, widespread corruption, and institutional atrophy in the 1990s and 2000s, providing the resources for the geographic and numerical expansion of armed groups in Colombia. They fuel much of the violence occurring in Colombian regions and pose one of the greatest risks to postconflict stability.

Illicit crop substitution was a central component of the agreement with FARC. Many of its provisions, such as a reform of the national cadaster to allow for the formalization of land titles and the disbursement of credits and loans to peasants and landowners in order to stimulate legal rural economies were closely linked to the rural reform component (Rettberg 2019a). Notwithstanding a significant institutional backing, (mainly the National Program for Illicit Crop Substitution (Programa Nacional Integral de Sustitución de Cultivos Ilícitos PNIS), which builds on decades of experience dealing with the drug problem), this aspect has been difficult to implement. This has less to do with institutional and security capacity in Colombia than with the ultimate limitations of a model that privileges domestic over systemic approaches to the drug trade, in which both supply and demand side need to be taken into account (Zuleta 2017).

Illustrating this fact, and contrary to expectations that crop substitution programs would stem the flow of drugs, illicit crops increased once peace negotiations started (UNODC 2019) (figure 6). This has been attributed, on the one hand, to the fact that FARC informed peasants in their area of influence that there would be programs for those cultivating crops, thereby encouraging many to plant, and, on the other, to the fact that new and old criminal organizations, including some with links to Mexican cartels (Bargent 2018), moved into illicit crop-controlled territories once FARC moved out, demanding peasants to comply with production quotas (Martínez and Zuleta 2019). This was facilitated by a steady supply of disenfranchised youth in Colombia's poorer regions 
and the outskirts of large metropolises who develop and control illicit markets. The fact that the number of cocaine users in the US, Colombia's biggest market, has increased, added incentives (figure 7).

Figure 6. Illicit crops (by hectare) and efforts to control them (manual eradication and aerial aspersion)

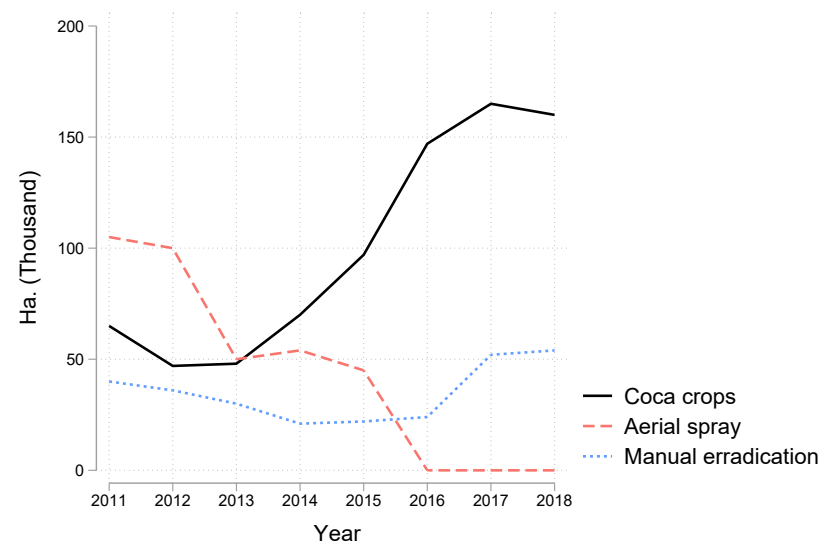

Source: Observatorio de Drogas de Colombia (2020). The continuous blue line marks the beginning of peace negotiations in 2012 and helps drive home the point that crops skyrocketed after negotiations started.

Figure 7. Cocaine Use Among US Citizens Aged 12 or Older, 2002 - 2018

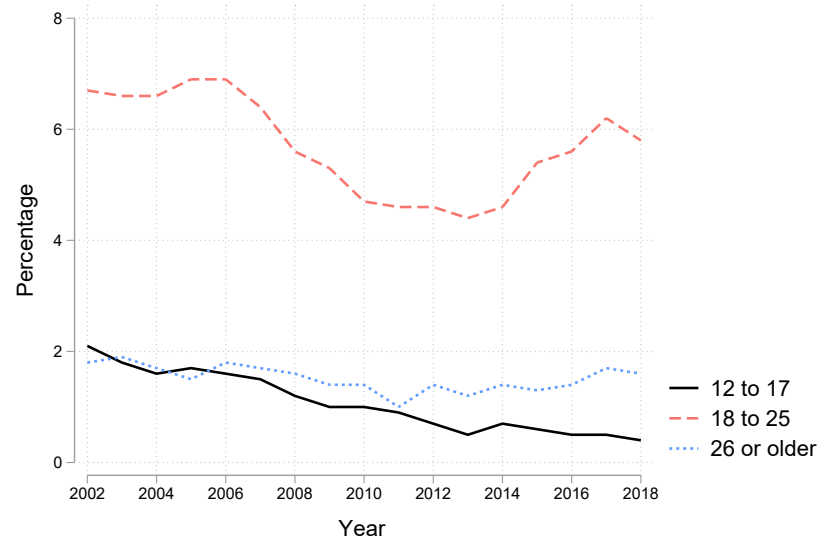

As a result, Colombia in 2019 faced renewed international and domestic backlash for its inability to control illicit crop production and providing tons of cocaine to consumers around the world (CNN 2019a). The domestic face of 
this, on the one hand, is ongoing violence in illicit crop-dominated areas, some of which is led by FARC dissidents. Trapped in the crossfire, as usual, are civilians and social leaders. On the other hand, illicit crops and the resulting violence fuel political opposition to the peace agreement with FARC and nostalgia for strong-hand approaches to security and crime. In such a context, the government's recent announcement that it intended to resume aerial aspersion (which has been questioned due to its potential health hazards, Isacson 2019) has thrived. ${ }^{4}$

\section{COLOMBIA AND VENEZUELA: TENSION WITH NO END IN SIGHT}

The fate of the peace agreement and the evolution of illicit crops are intrinsically linked to Colombia's relationship with neighboring Venezuela. Beyond the two countries' historically close ties in cultural, commercial, and political terms, 2019 brought home their interdependence in two salient ways: On the one hand, the tense relationship between the Colombian government and the Maduro regime in Venezuela, which has been fed by animosities across the Latin American region; on the other hand, the human face of the Venezuelan crisis, illustrated by the steady flow of migrants into Colombia across porous borders, marked by illicit economies and weak formal governance by either of the two countries (Idler 2019). Both phenomena impact Colombian security, the peace agreement's implementation, domestic politics and foreign policy, and Colombia's fiscal capacity to address the growing demands of migrants.

2019 began with the self-proclamation of Juan Guaidó as president of the National Assembly, in January. This watershed event was followed by his immediate recognition as interim president by the Colombian and other governments worldwide-including the European Union and the US - in the hope that this would produce a transition in the Venezuelan regime. While the region held its breath, Colombian President Iván Duque took the initiative to launch a US-supported diplomatic effort to force elections in Venezuela (Mijares and Cardozo 2020). Based on his November 2018 call to develop a "diplomatic fence" against the Maduro regime, the "Lima Group", a multilateral body developed in 2017 to find a peaceful solution to the crisis in Venezuela, developed a multi-tiered agenda to strengthen Venezuela's opposition, demand the release of political prisoners, end human rights violations, and call for free elections.

Following Colombia's move, in February 2019, the government of Nicolás Maduro cut diplomatic ties and closed the border with Colombia (BBC 2019a), and strengthened relations with Cuba, China, and Russia. In response, a USAID humanitarian aid convoy was sent from Colombia to the border with Venezu-

As of June 2020, aerial aspersion had not resumed due to legal impediments posed by the Constitutional Court and opposition by communities (El Nuevo Siglo 2020). 
ela (New York Times 2019) and a concert was held in solidarity with the Venezuelan people (CNN 2019b). Neither was successful in toppling Maduro, nor were several diplomatic efforts developed throughout the year, led by the UN, the US and Norway, among others (Deutsche Welle 2019). Despite aggressive bilateral rhetoric and an ongoing economic crisis, by the end of 2019 Guaidó and much of the diplomatic activity against Maduro had lost steam and the regime appears firmly in power.

In part, this has been helped by the fact that more than four million people have fled Venezuela due to food and medication shortages (International Crisis Group 2019), relieving pressure on available resources in their home country, depriving the Venezuelan opposition of necessary street force, providing new opportunities to migrants and supplying migrants with the possibility to send remittances to loved ones back home. According to official sources, around 1,7 million Venezuelans are now in Colombia (figure 8). However, extra-official data suggest the number might be closer to three million, including a shifting border population and a significant flow through Colombia towards the South of the sub-continent.

Figure 8. Venezuelans who have entered Colombian territory as registered with Colombian migration authorities

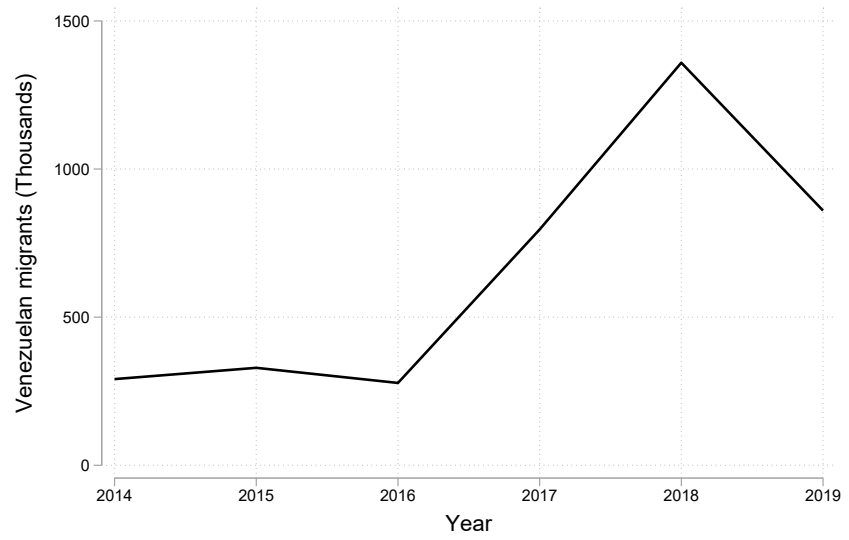

Fuente: Migración Colombia 2019.

Colombia has had an overall welcoming policy for migrants, aided by European Union and US resources. Expired Venezuelan passports are automatically granted a two-year extension, and babies born to Venezuelan migrants in Colombia are automatically granted Colombian citizenship since August 2019, a measure that benefits more than 25,000 children born between 2015 and 2021 (Registraduría Nacional del Estado Civil 2019). 
Although they have gained Colombia's government international appreciation, many of these measures are not supported by Colombians. Xenofobia, or the fear of foreigners, has climbed in the past years (figure 9), as people fear their jobs will be lost to equally or better qualified Venezuelans who work for lower wages and longer hours (La Silla Vacía 2020, in fact, only 25 percent of migrants work under formal contracts, Morales 2020). 71 percent of participants in a Revista Semana survey said that migrants increase Colombia's poverty (Semana 2020a). In a different poll, 69 percent didn't want Venezuelans as neighbors (Cifras y Conceptos 2020 , figure 10). Some fear that the presence of migrants is responsible for flares of violence in border areas and for insecurity in urban areas.

Figure 9. Gallup Poll, agreement about whether the Colombian government should embrace Venezuelans

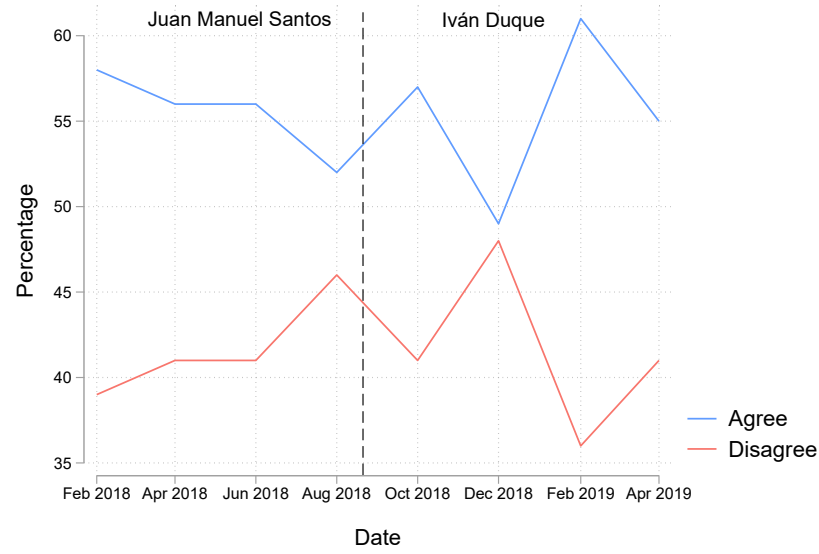

Source: Invamer, 2019.

Figure 10. Of the following groups of people, who would you not like to have as neighbors? (left) Would you like having an immigrant as a neighbor? (right)

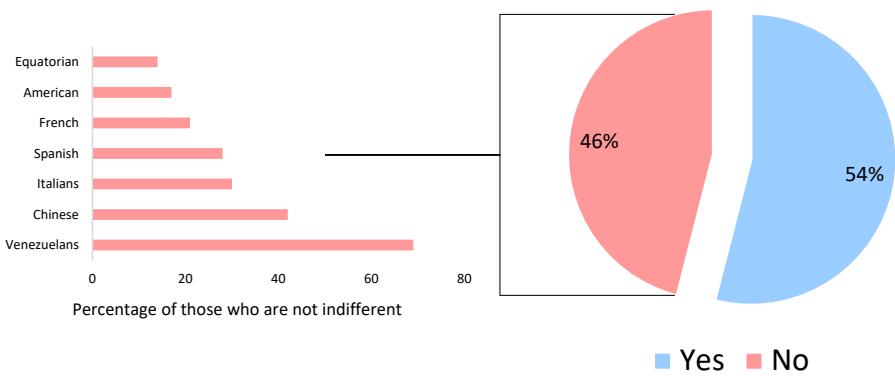


The Colombian peace process, Colombian security, illicit crops, the drug trade, and Venezuela are closely intertwined in many ways. At a UN General Assembly meeting in September president Duque levied accusations that the Maduro regime is funded by the drug trade (Semana 2019b). Unrest and lawlessness in border areas fuels insecurity in Colombia and provides fertile soil for illicit economies, as shown by hikes in illicit crops. In regions where peace agreement implementation is most needed in the form of territorial peace programs (PDETs), fears are rising that the peace budget will be increasingly limited as a result of the constant flow of resources towards migrants. In large Colombian cities, fears abound that Venezuelans are taking people's jobs and feeding petty crime.

\section{SOCIAL UNREST: NATIONAL STOPPAGES, "CACEROLAZOS" AND DISAPPOINTMENT}

Compounding all three topics mentioned above, the end of 2019 was marked by a wave of social unrest, as swept through other countries of Latin America. The protest movement began months earlier with students expressing demands for affordable quality education (Borda 2020). As a result, a strike originally planned by labor unions for November $21^{\text {st }}$ grew exponentially with students, feminists opposing patriarchal structures, environmentalists opposing deforestation, mining activities, and the sale and export of shark fins, defendants of the peace agreement demanding speedier and full implementation, peasant communities criticizing the slow speed of illicit crop substitution, victims decrying failure in reparation payments and attacks on historical memory, indigenous leaders demanding protection of their ancestral lands, public teachers demanding job security and better wages, Human Rights activists demanding an end to the killing of social leaders and a reform of the Police, anti-corruption activists, critics of the banks, of neoliberal politics, and of free trade agreements, parties on the political Left, and skeptics of the political system, in general. As a result, a diverse amalgam of people poured to the streets one day after the other by the thousands in an outburst of social malaise (Abitbol 2019; Botero and Otero 2019; Dedios 2019). The outburst was facilitated by the speed of message-and slogan-sharing on social networks (especially through whatsapp) and complemented by a strong artistic and performance component. A crucial trademark of the moment was daily pot-banging (cacerolazo), which allowed people to express their discontent whether they went to the street or not.

As suggested by Botero and Otero (2019), while reasons for the national outpouring were diverse, frustration with the slow speed of peace agreement implementation as well as the emergence of topics that the conflict had played down for decades played a significant role. In addition, however, the central role of cities and urban dissatisfaction as described by Dedios (2019) also needs to be factored in, as they capture best the clash between economic expectations of social mobility resulting from years of economic growth across the country 
and institutional capacity to deliver. As a result, the 2019 social unrest may also reflect the proven revolution of rising expectations (Hirschman and Rothschild 1973) or the possibility that economic progress breeds political instability.

Although most protest occurred peacefully, violence and vandalism-and, often, simply the fear that they might happen-were also present. As a result, several cities declared curfews, a measure that Colombian governments had not implemented for decades. The Police and the military were on maximum alert. The death of a young man on the night of November $25^{\text {th }}$ provided the movement with a face and stirred the outrage. He had been part of a group of protesting students and was accidentally shot by a "bean bag" projectile typically used by anti-riot police (BBC 2019b).

Amidst the unrest, there were significant rumors that Venezuelans had been involved in some of the looting and vandalism, some even on behalf of the Maduro regime itself. The Colombian vice-president, for example, announced that protest were being promoted from abroad (illustration 2), a message that was replicated by government legislators (Cabal 2019). In response, dozens of Venezuelans were "sent back" to border areas with Venezuela (Cuestión Pública 2019).

Illustration 2. Tweet by Marta Lucia Ramírez, Colombia's vice-president: "Violence has been promoted from abroad for the protests on November $21^{\text {st }}$, people arriving from Venezuela have been captured who were seeking to infiltrate the marches to affect public order. In these moments, democracy is under threat in Latin America."

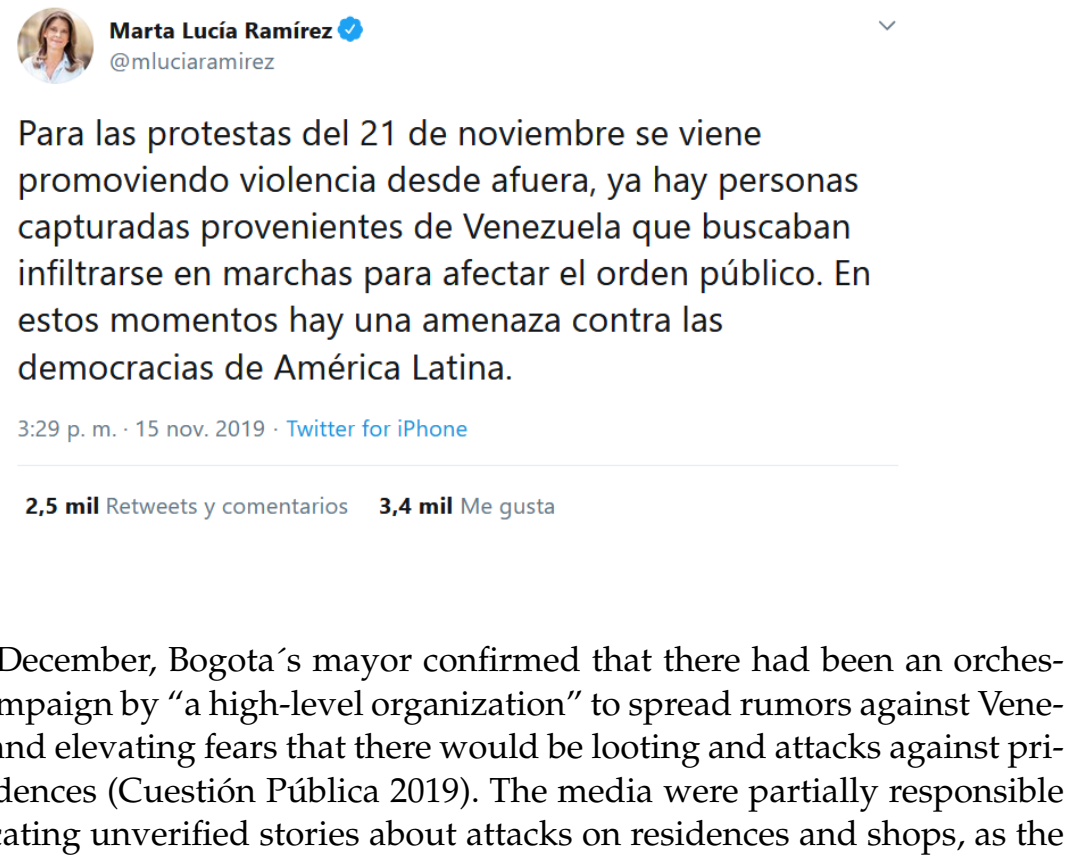

Later in December, Bogota's mayor confirmed that there had been an orchestrated campaign by "a high-level organization" to spread rumors against Venezuelans and elevating fears that there would be looting and attacks against private residences (Cuestión Pública 2019). The media were partially responsible for replicating unverified stories about attacks on residences and shops, as the 
same videos were played and distributed over and over again attributing the same events to different locations across the city.

Once the national panic and anxiety subsided, people's attention was drawn back to the strike itself. However, it now became clear that there were significant limits in terms of efficacy and impact of such a wildly heterogeneous and leader-less movement, and that the government and the traditional parties', too, lacked the capacity to understand and respond to the outburst. As a result, the weeks following the strike saw significant fragmentation and opportunistic behavior by many sides.

On the one hand, the strike organizers disagreed amongst themselves over whether the strike should go on indefinitely or whether it was acceptable to engage in negotiations with the government. Some even advocated for the resignation of president Duque. In addition, some sectors within the strike committee added new issues to an already comprehensive list of demands, including the resumption of peace talks with the ELN, the dismantling of the Colombian anti-riot police, the compulsory monitoring and conduction of research on AIDS, Colombia's retreat from OECD, the nationalization of oil resources, and the hiring of national artists in cultural events funded by public resources (Comité Nacional del Paro 2019). Finally, labor unions, which are weak in Colombia (Urrutia 2016), are seen as privileged among the mass of formal and informal workers and were unlikely representatives of such a diverse movement. The fractures became complete with the emergence of an anti-strike committee in February 2020, which demanded a reversal of the Special Peace Jurisdiction, improved security in cities and rural areas, a reform of the Interamerican Human Rights System, life imprisonment for convicted murderers and child rapists, among other things, illustrating the demands of its supporters within groups on the Right of the political spectrum, including retired military officers (Hernández 2020).

On the other hand, the government called leaders across the country-including but not limited to the organizations supporting the strike-to join a "Grand National Conversation". This effort, too, was marked by deficient methodology and lack of clarity about its exact purpose, mandate, and possible outcomes. Strike organizers disagreed with the government over whether they were in a negotiation with binding power or in a working group to make recommendations and monitor the relevant institutions in charge of each of the topics on the table. Even without a "divide-and-conquer" strategy, fractures among the various striking organizations made it easy for national authorities to delegitimize the representation and play down the voice of the protests.

Social network activism, too, soon reached its limits, illustrating some of the pitfalls of "millennial activism" (Milkmann 2017) as well as classical collective action problems. In the race towards visibility, some of the more entertaining activity appeared to trivialize or overshadow some of the very serious issues at stake. Enthusiasm for the manifestations waded as the year drew to a close, 
the divisions seemed insurmountable, and no clear leadership emerged, despite efforts by some parties to steer them into their political camp. Remarkably much of this unrest took place at the same time as economic authorities were announcing that Colombia had grown above 3 percent in 2019, the highest rate in the past five years (Caracol 2020; DANE 2020).

Interpretations of the protests range from suggestions that they reflect the emergence of a politically active middle class that has been economically empowered over the past years and that resents the failures of political leadership, to contagion from other countries, to improved political freedom and a renewed interest in politics beyond conflict, now that this issue no longer dominates most people's concerns. As shown in this section, all of these interpretations may hold some aspect of truth.

\section{DISCUSSION}

As mentioned in the introduction and should become clear in the previous sections, the four topics discussed here-the peace process, illicit crops, Venezuela, and the national strike-are profoundly intertwined. Taken together, they point to the multiple transitions the country is undergoing, which illustrate the sides of the Colombian paradox of plenty: superior economic performance and institutional stability at the same time as growing social unrest and pervasive violence.

On the one hand, a growing number of stronger and better funded institutions provide the background against which the Colombian state has been able to increase its presence in more regions and more policy areas than ever before. The fact that institutions constitute the main back-and battleground against which much of ongoing debates take place speaks to this assertion. In contrast with other times in Colombian and Latin American history, when discrepancies and political competition were expressed and solved extra-institutionally and often violently, the larger picture provided by this document should underscore how much more is now debated and solved in formal institutional settings with rules that most political leaders abide by and compete over. This is the case of the discussions over transitional justice (which are led by agreement-related institutions such as the Special Peace Jurisdiction, Congress, the Presidency, political parties and many social organizations), illicit crops (which are led by academic institutions, international organizations, and organized communities), and migration (which take place at the level of national and local governments, foreign donors, and regional bodies).

In addition, although only partially implemented, the peace agreement's ambitions as well as the preceding peacebuilding infrastructure are producing significant change in specific areas of the country and on matters related to transitional justice and truth, improved political participation, and territorial peace. Much of this has been made possible due to the country's improving economic 
performance which has provided the resources, the technical capacity, and the international partnerships required for Colombia to address its many structural problems. Despite the restlessness and ongoing turmoil often conveyed in social networks and public debates, this should be a crucial lesson learned from the year 2019 .

On the other hand, people's appetite for greater freedom, participation, and speed in social policy, as expressed in the November protests (albeit as vaguely and diffusely as it was), confirms that improved economic performance and institutional capacity are no guarantee for social peace. Fears run high of losing recently obtained or still-to-be-consolidated rights and conditions, a sentiment that spurs the feeling of competition over scarce resources and the concomitant rising xenophobia among many in the general population. At the same time, the ongoing drug trade and illicit crops remind us of the limitations imposed by this systemic and transnational problem, which is unlikely to end anytime soon. 2019 again showed how much violence within and across Colombian borders the phenomenon is still causing and will continue to cause.

\section{VII.CONCLUSIONS}

This article has provided an overview of Colombia during 2019, emphasizing four issue areas: the peace agreement with FARC, illicit crops, the Venezuela migration crisis, and end-of-the-year protests. Looking back at 2019 from the future, when all Latin American countries are struggling with the political, social, and economic effects of the Covid-19 health crisis, the situation described here provides both reasons for hope and for concern. Peace with FARC amounted to an eye opener and action driver for many in Colombian society. In other words, peace in "muddling through" modus has been able to take roots and is unlikely to be rolled back. However, other structural issues need to be addressed in full, such as corruption, inequality, and the natural environment, all compounded by the social and economic consequences of the Covid-19 crisis, which will slow economic growth, a reduction of public resources and an increase in social needs. Violence generally has gone down but has shown to be stubborn in illicit crops-dominated areas, where criminal organizations have benefited from the health crisis to firm their grip of territories. Finally, the regional effects of the Venezuelan crisis are still far from subsiding, posing ongoing challenges to recipient countries, among them Colombia. The coming months and years will tell which trend prevails.

\section{REFERENCES}

Abitbol, Pablo. 2019, December. “¿Por qué protestan en Colombia? Movilizaciones, reclamos de paz y crisis de la derecha." Nueva Sociedad. Retrieved from https://nuso.org/articulo/por-que-protestan-en-colombia/ 
Acemoglu, Daron, Leopoldo Fergusson, James Robinson, Dario Romero, and Juan F. Vargas. 2018. The Perils of High-Powered Incentives: Evidence from Colombia's False Positives. NBER Working Paper No. 22617.

ARN. 2020a. Infografías: Espacios Territoriales de Capacitación y Reincorporación. Agencia para la Reincorporación y la Normalización. Retrieved from http://www.reincorporacion.gov.co/es/reincorporacion/Documents/ETCR-simple-Pagina-WEB-06022019. pdf

ARN. 2020b. Beneficios económicos y sociales. Agencia para la Reincorporación y la Normalización. Retrieved from http://www.reincorporacion.gov.co/es/reincorporacion/Paginas/Beneficios-economicos-y-sociales.aspx

BBC. 2019a, 23 February. "Crisis en Venezuela: Maduro rompe relaciones diplomáticas con Colombia y da 24 horas a sus diplomáticos para que abandonen el país." BBC News. Retrieved from https://www.bbc.com/mundo/noticias-america-latina-47341056

BBC. 2019b, 28 November. "Crisis en Colombia | "Homicidio": así murió Dilan Cruz, el joven manifestante símbolo de las protestas en Colombia." BBC News. Retrieved from https://www.bbc.com/mundo/noticias-america-latina-50593913

Bargent, James. 2018. "What Is the Mexican Cartels' Strategy for Post-FARC Colombia?" Insight Crime. Retrieved 1 August from https://www.insightcrime.org/news/analysis/ what-is-the-mexican-cartels-strategy-for-post-farc-colombia/

Borda, Sandra. 2020. Parar para Avanzar. Crónica del Movimiento Estudiantil durante el histórico paro nacional de 2019. Bogotá: Editorial Planeta.

Botero, Sandra, and Silvia Otero Bahamón. 2019, 25 November. “El dividendo agridulce de la paz truncada." Centro de Investigación Periodística (CIPER). Retrieved from https:// ciperchile.cl/2019/11/25/el-dividendo-agridulce-de-la-paz-truncada/

Cabal, María Fernanda. 2019, 14 November. Twitter. Retrieved from https:/ / twitter.com/Ma$\mathrm{riaFdaCabal} /$ status $/ 1195148349524996096 ? \mathrm{~s}=20$

Caracol Noticias. 2020, February 14. “Economía colombiana creció 3.3 \% en 2019." Retrieved from https://noticias th.caracoltv.com/economia/economia-colombiana-crecio-3-3en-2019-segun-el-dane

Cifras y Conceptos, 2020, May. "Encuesta Polimétrica Colombia." Retrieved from https:// cifrasyconceptos.com/productos-polimetrica/

CNN. 2019a. "Trump critica a Iván Duque por no frenar el tráfico de drogas de Colombia a EE.UU.: "No ha hecho nada por nosotros." CNN en Español. Retrieved from https:/ / cnnespanol.cnn.com/2019/04/01/trump-critica-a-ivan-duque-por-no-frenar-el-trafico-de-drogas-de-colombia-a-ee-uu-no-ha-hecho-nada-por-nosotros /

CNN. 2019b. "Venezuela Aid Live: el concierto que hizo vibrar la frontera de Colombia y Venezuela." CNN en Español. February 22 ${ }^{\text {nd }}$. Retrieved from https://cnnespanol.cnn. com/2019/02/22/venezuela-aid-live-el-concierto-que-hizo-vibrar-la-frontera-de-colombia-y-venezuela/

Cifuentes, Carlos Felipe, and Rodrigo Mezú (eds.). 2020. Oropéndola: Volando con verdad. Bogotá: Fuerza Aérea Colombiana and Editorial Ibañez.

Centro de Memoria Histórica. 2012. Encuesta nacional: ¿Qué piensan los colombianos después de siete años de justicia y paz? Centro de Memoria Histórica, OIM, Fundación Social, Universidad de los Andes. Retrieved from http://www.centrodememoriahistorica.gov. co/descargas/informes2012/encuesta.pdf

Cuestión Pública. 2019, December 19. "Medios, caos, pánico y desinformación en el toque de queda." Cuestión Pública. Retrieved from https://cuestionpublica.com/medios-caos-panico-desinformacion-en-el-toque-de-queda/

Comité Nacional del Paro. 2019, December 13. "Agenda del Comité Nacional de Paro para la negociación con el Gobierno nacional.", Retrieved from http:/ / www.indepaz.org. co/agenda-del-comite-nacional-de-paro-para-la-negociacion-con-el-gobierno-nacional/.

Congreso Visible. 2020. Database, https://congresovisible.uniandes.edu.co/ Congreso Visible, Universidad de los Andes. 
Consejería Presidencial para la Estabilización y la Consolidación. 2020. “Fondo Colombia en Paz." Retrieved from http://www.posconflicto.gov.co/consejeria/Paginas/Fondo-Colombia-en-Paz.aspx

Dedios, María Cecilia. 2019, November 29. "El paro no se entiende si no se entienden las ciudades." La Silla Vacía. Retrieved from https://lasillavacia.com/silla-llena/red-social/paro-no-se-entiende-si-no-se-entienden-las-ciudades-71806

Departamento Administrativo (DANE). 2020. "Producto Interno Bruto (PIB) Base 2015." Retrieved from https://www.dane.gov.co/index.php/estadisticas-por-tema/cuentas-nacionales/cuentas-nacionales-trimestrales

Deutsche Welle. 2019, September 16. "Guaidó abandona también el diálogo de Barbados." Deutsche Welle. Retrieved from https://p.dw.com/p/3PeLs.

El Nuevo Siglo. 2020, May 19. "Se embolata reinicio de aspersión aérea con glifosato a cultivos ilícitos." El Nuevo Siglo. Retrieved from https://www.elnuevosiglo.com.co/articulos/05-2020-se-embolata-reinicio-de-aspersion-aerea-con-glifosato-cultivos-ilicitos

El Tiempo. 2020, May 31. "Disidencias de las Farc duplican su número de hombres en solo 12 meses." El Tiempo. Retrieved from https://www.eltiempo.com/unidad-investigativa/disidencias-de-las-farc-duplican-su-numero-de-hombres-en-armas-solo-12-meses-501426

El Tiempo. 2019, October 27. "El debut de la Farc en la arena electoral regional." El Tiempo. Retrieved from https://www.eltiempo.com/politica/partidos-politicos/como-lefue-al-partido-farc-en-las-elecciones-regionales-de-2019-427788

Fundación Ideas para la Paz. 2019. Qué hacer con el ELN? Opciones ante una derrota militar lejana y un diálogo improbable. Retrieved from http://ideaspaz.org/media/website/FIP_NE_QuehacerELN_Final.pdf

Gallup. 2019. "Colombia Mayo 2019, Nr. 130", in La República. Retrieved from https://imgcdn.larepublica.co/cms/2019/05/17085310/031800190000-GALLUP-POLL-130. pdf, slide 75 .

Hernández, Carlos. 2020, February 4. "Al Comité del Paro le salió una disidencia." La Silla Vacía. Retrieved from https://lasillavacia.com/al-comite-del-paro-le-salio-disidencia-75407

Hirschman, Albert O., and Michael Rothschild. 1973. "The Changing Tolerance for Income Inequality in the Course of Economic Development." The Quarterly Journal of Economics, 87(4): 544-566.

Idler, Annette. 2019. Borderland Battles. Violence, Crime, and Governance at the Edges of Colombia's War. Oxford: Oxford University Press.

Institute for Integrated Transitions (IFIT). 2018. The Colombian Peace Talks: Practical Lessons for Negotiators Worldwide. Retrieved from http:/ / www.ifit-transitions.org/resources/ publications/major-publications-briefings/the-colombian-peace-talks-practical-lessons-for-negotiators-worldwide/colombia-peace-talks-final-web-25-sept-1.pdf/ view

International Crisis Group. 2019. A Glimmer of Light in Venezuela's Gloom, Report No. 75. Retrieved from https://www.crisisgroup.org/latin-america-caribbean/andes/venezuela/75-glimmer-light-venezuelas-gloom

International Commission of Jurists. 2019. Colombia: The Special Jurisdiction for Peace, Analysis One Year and a Half After its Entry into Operation. Retrieved from https:// www.icj.org/wp-content/uploads/2020/05/Colombia-Jurisd-para-la-paz-PUBLICATIONS-Reports-Fact-finding-mission-report-2019-ENG.pdf

Invamer. 2019. Encuesta Invamer Gallup-Poll Colombia. December. Retrieved from private sources.

Isacson, Adam. 2019. Restarting Aerial Fumigation of Drug Crops in Colombia is a Mistake, Washington Office for Latin America (WOLA). Retrieved from https://www.wola. org/analysis/restarting-aerial-fumigation-of-drug-crops-in-colombia-is-a-mistake/

Jurisdicción Especial para la Paz (JEP). 2020a. Comprehensive System of Truth, Justice, Reparation, and Non-Repetition (SIVJRNR). Retrieved from https://www.jep.gov.co/Infografas/SIVJRNR_EN.pdf 
Jurisdicción Especial para la Paz (JEP). 2020b. JEP en cifras. February. Retrieved from https:/ / www.jep.gov.co/Infografas/cifras-febrero-28.pdf

Jurisdicción Especial para la Paz (JEP). 2019. Diligencia de prospección y exhumación en cementerio de Dabeiba (Antioquia) por parte de la JEP. Comunicado 180. Retrieved from https:/ / www.jep.gov.co/Sala-de-Prensa/Paginas/Comunicado-180-de-2019----Diligencia-de-prospecci\%C3\%B3n-y-exhumaci\%C3\%B3n-en-cementerio-de-Dabeiba-(Antioquia)-por-parte-de-la-JEP.aspx

Kurtenbach, Sabine and Angelika Rettberg (eds.). 2020. War Economies and Post-War Crime. ThirdWorlds Series, Routledge - Taylor and Francis.

Latin American Public Opinion Project (LAPOP). 2018. Barómetro de las Américas 2018: Paz, Posconflicto y Reconciliación. Vanderbilt University. Retrieved from https://www. vanderbilt.edu/lapop/colombia/Colombia_2018_Informe_Paz_conflicto_y_reconciliacion_W_11.07.19.pdf

La Silla Vacía. 2020, April 1. "La xenofobia contra venezolanos recrudece en medio de la pandemia." Retrieved from https://lasillavacia.com/xenofobia-contra-venezolanos-recrudece-medio-pandemia-76074.

Martínez, Tatiana and Hernando Zuleta. 2019. "Cultivos de Coca y Violencia: El cambio después de iniciados los diálogos de paz." Documento CEDE 017408, Universidad de los Andes.

Mijares, Víctor M. and Alejandro Cardozo Uzcátegui. 2020. "Militares bajo control." Foreign Affairs Latinoamérica, 20(2): 16-23. Retrieved from www.fal.itam.mx

Migración Colombia. 2019, February 25. "Venezolanos en Colombia, corte 31 de diciembre de 2019." Retrieved from https://www.migracioncolombia.gov.co/infografias/259-infografias-2020/total-de-venezolanos-en-colombia-corte-a-31-de-diciembre-de-2019.

Milkman, Ruth. 2017. "A New Political Generation: Millennials and the Post-2008 Wave of Protest." American Sociological Review 82(1): 1-31.

Ministerio de Defensa Nacional. 2020, June. Logros de la política de defensa y seguridad: viceministerio para las políticas y asuntos internacionales Dirección de Estudios Estratégicos. Retrieved from https://www.mindefensa.gov.co/irj/go/km/docs/ Mindefensa/Documentos/descargas/estudios_sectoriales/info_estadistica/Logros_Sector_Defensa.pdf

Misión de Observación Electoral. 2018. Resultados electorales: elecciones legislativas y consultas interpartidistas. Misión de Observación Electoral, February 2020. Retrieved from https://moe.org.co/wp-content/uploads/2018/06/Resultados-Congreso-2018.pdf

Morales, Martha. 2020, February 26. "3 de cada 4 venezolanos trabajan en Colombia sin un contrato laboral." El Tiempo. Retrieved from https://www.eltiempo.com/economia/ sectores/realidad-laboral-de-venezolanos-en-colombia-466664

Nasi, Carlo, and Angelika Rettberg. 2019. "Colombia's Farewell to Civil War: Reaching Closure in a Divided Society." In How Negotiations End: Negotiating Behavior in the Endgame, edited by William Zartman. Cambridge: Cambridge University Press, 62 - 82.

New York Times. 2019, March 10. "Footage Contradicts U.S. Claim That Nicolás Maduro Burned Aid Convoy." New York Times. Retrieved from https://www.nytimes. com/2019/03/10/world/americas/venezuela-aid-fire-video.html

Observatorio de la Democracia. 2019. Barómetro de las Américas 2018. Colombia, un país más allá del conflicto 2019. Retrieved from https://obsdemocracia.org/barometro-de-las-americas /

Observatorio de Drogas de Colombia. 2020, February. Problemática en oferta de drogas. Retrieved from http://www.odc.gov.co/sidco/perfiles/estadisticas-nacionales

Registraduría Nacional del Estado Civil. 2019, August 5. "Colombia concede nacionalidad a hijos de migrantes venezolanos nacidos en el territorio nacional." Retrieved from https://www.registraduria.gov.co/Colombia-concede-nacionalidad-a-hijos-de-migrantes-venezolanos-nacidos-en-el.html. 
Rettberg, Angelika. 2015. "Victims of the Colombian Armed Conflict: The Birth of a Political Actor." In Colombia's Political Economy at the Outset of the 21st Century: From Uribe to Santos and Beyond, edited by Bruce Bagley and Jonathan Rosen. Lexington Books, 111 -139 .

Rettberg, Angelika. 2019a. "Peace-Making Amidst an Unfinished Social Contract: The Case of Colombia." Journal of Intervention and Statebuilding, 13(3):84-100.

Rettberg, Angelika. 2019b. “¿Cómo le ha ido a la FARC en el Congreso (2018 - 2019)?”, Twitter thread, https://twitter.com/rettberg_a/status/1178665773314777089

Rettberg, Angelika. 2020. "Violencia en América Latina hoy: manifestaciones e impactos." Revista de Estudios Sociales 73:2-17.

Saffon, María Paula, and Diana Güiza. 2019. “Colombia in 2018: Between the Failure of Peace and the Beginning of Programmatic Politics." Revista de Ciencia Política 39(2): 217-237.

Semana. 2019a, October 28. "La derrota del uribismo: ¿es un mensaje para el gobierno Duque?" Retrieved from https://www.semana.com/nacion/articulo/el-uribismo-perdio-en-las-elecciones-regionales/638176

Semana. 2019b, September 27. “En la ONU, Duque presentó foto del ELN en Venezuela que es de 2013 y correspondería a hechos ocurridos en el Cauca." Retrieved from https:/ / www.semana.com/nacion/articulo/duque-presenta-a-naciones-unidas-una-foto-falsa-del-eln-en-venezuela/633522

Semana. 2020a. "Percepción de la integración de los migrantes en Colombia en tiempos de coronavirus", Proyecto Migración Venezuela. Retrieved from https://s3.amazonaws. com/semanaruralvzla/documentos/1590818285_boletin_discriminacion2020pdf

Semana. 2020b. "Especiales Semana. Cementerio del Horror: Los horrores de Dabeiba". Retrieved from https://especiales.semana.com/cementerio-del-horror-falsos-positivos/crimenes-del-ejercito-nacional-en-dabeiba.html

Sikkink, Kathryn, Phuong N. Pham, Douglas A. Johnson, Bridget Marchesi, Peter Dixon, and Patrick Vinck. 2015. An Evaluation of Comprehensive Reparations Measures in Colombia: Accomplishments and Challenges. Cambridge: Carr Center for Human Rights Policy.

Substance Abuse and Mental Health Services Administration (SAMHSA). 2019. Key Substance Use and Mental Health Indicators in the United States: Results from the 2018 National Survey on Drug Use and Health. Retrieved from https://www.samhsa.gov/data/sites/ default/files/cbhsq-reports/NSDUHNationalFindingsReport2018/NSDUHNationalFindingsReport2018.pdf

United Nations News Centre Press (UN). 2016, September 26. "As Colombians bid farewell to 'decades of flames,' Ban pledges UN support to historic peace deal." Retrieved from http://www.un.org/apps/news/story.asp?NewsID=55127\#.WJYrnvnhCUk.

United Nation High Commissioner for Human Rights. 2020. Situation of human rights in Colombia - Report of the United Nations High Commissioner for Human Rights (A/ HRC/43/3/Add.3). Retrieved from https://reliefweb.int/report/colombia/situation-human-rights-colombia-report-united-nations-high-commissioner-human-rights

UNOCHA. 2019, February. Humanitarian needs overview: Colombia. Retrieved from https://www.humanitarianresponse.info/sites/www.humanitarianresponse.info/ files/documents/files/14012019_hno_2019_es.pdf

United Nations Office against Drugs and Crime (UNODC). 2019. Informe de monitoreo de territorios afectados por cultivos ilícitos 2018. Bogotá: SIMCI-UNODC.

United Nations Verification Mission. 2019, December 30. "Press Release Report of the Secretary-General on the Verification Mission in Colombia." Retrieved from https:/ / colombia.unmissions.org/en/press-release-report-secretary-general-un-verification-mission-colombia

Urrutia, Miguel. 2016. Historia del sindicalismo en Colombia, 1850-2013. Bogotá: Ediciones Uniandes.

Victims' Unit. 2020. "Registro Único de Víctimas." Retrieved from https:/ /www.unidadvictimas.gov.co/es/registro-unico-de-victimas-ruv/37394 
World Bank. 2020, June 4. "GDP growth (annual \%) - Colombia", World Bank national accounts data, and OECD National Accounts data files. Retrieved from https://data. worldbank.org/indicator/NY.GDP.MKTP.KD.ZG?end=2018\&locations=CO\&star$\mathrm{t}=1961$ \&view $=$ chart

Zuleta, Hernando. 2017, June. Coca, cocaína y narcotráfico. Documento CEDE, 42. Retrieved from https://economia.uniandes.edu.co/components/com_booklibrary/ebooks/ dcede2017-42.pdf

Received: 12 june 2020

Accepted: 31 july 2020

Angelika Rettberg is a professor at the Political Science Department at Universidad de los Andes (Bogotá - Colombia). She earned her Ph.D. from Boston University. Since 2017 she is a Global Fellow at the Peace Research Institute of Oslo (PRIO), a visiting fellow at the German Institute for Global and Area Studies (GIGA) and a visiting fellow at the Centre for Women, Peace and Security at the London School of Economics (LSE). Since 2019, she is a co-director within the Gender, Justice, and Security Hub at the London School of Economics. Her research has focused on the private sector as a political actor and, specifically, on business behavior in contexts of armed conflict and peacebuilding. She has also been involved in research about the relationship between legal resources, armed conflict, and crime as well as the dynamics of transitional justice and reconciliation. She is a member of several editorial boards, including Security Dialogue, Colombia Internacional, and Revista de Estudios Sociales. In 2018 she served as a negotiator for the Colombian government in the peace talks with the Ejército de Liberación Nacional (ELN). 